\title{
The influences of lime and irrigation water on arsenic accumulation of rice, maize and mungbean in the nethouse condition
}

\author{
Nguyen Van Chuong* \\ Department of Crop Science, Agricultural Faculty of An Giang University - Vietnam National University, Long Xuyen city 880000, Vietnam
}

Received: 25 August 2021 / Received in revised form: 25 November 2021 / Accepted: 20 December 2021

\begin{abstract}
This research found the great hold of liming, soils and irrigation water on the arsenic (As) accumulation of rice, maize and mung bean in the nethouse research. Two greenhouse experiments had various plant types of rice, maize and mung bean with two soils inside and outside the dyke, two irrigated waters of 0.0 and $200 \mu \mathrm{g}$ As/ $/ \mathrm{L}$ and three different lime ratios $(0,7.0$ and 9.0 tons $\mathrm{CaO} / \mathrm{ha})$. The whole treatments were twenty one (12 treatments of experiment 1 and 9 of experiment 2) with 4 repetitions. The results of this study showed that the lime application raised both soil $\mathrm{pH}$ and crop yield. The arsenic (As) absorption of plant bodies in stems and seeds inside the dyke increased from 67.8 to $68.3 \%$ higher than those outside the dyke, respectively. The arsenic contents of stems and seeds with the treatments of $200 \mu \mathrm{g} \mathrm{As} / \mathrm{L}$ irrigation water were higher from 81.5 to $89.4 \%$ than that of non As irrigation water, respectively. The lime supplementation of 7.0 and 9.0 tons $\mathrm{CaO}$ per ha reduced the As accumulation of stems and seeds of rice, maize and mung bean was lower than the one without lime supplement from 38.6 (stems) and 54.5 (seeds). Mung bean absorbed the highest As, followed by rice and maize with the lowest As value. However, the lime supplementation of 9.0 tons $\mathrm{CaO} / \mathrm{ha}$ had so high soil $\mathrm{pH}$ of soil that restricted the growth and yield of crops. More different lime concentrations need to search for more new details and new discovery of positive effects of this research.
\end{abstract}

Key words: Arsenic; lime; maize; mung bean; rice

\section{Introduction}

The agricultural cultivation has been planting and watering on the As contaminated soils and waters, which absorb the high As content of their stems and seeds and reduce the plant production. Local tillers irrigate for their fields by deep wells, which are mainly the As pollution source to raise the As concentration of soils and products of agriculture [1,2,3,4,5]. Relations between soil the As content of pollution irrigation waters, soils and seeds showed the positive correlation coefficients [6]. The As concentration of forty deep well water samples exceeded WHO and Vietnam standards (100 to 461 ppb).

Rice, maize and mung bean are the mainstay sources of foods in Vietnam and Asian people in which they have been cultivated in Asian countries and act as the supplementing sources of essential nutrition for human. The recent studies have found out the As accumulation on stems and seeds of rice, maize and mung bean [1,2]. Local tillers (30-92.6\%) have been using the deep well water to watering for their crops [1,6]. When the tills of rice, mung bean and maize absorbed by the high As accumulation of stems and seeds came from As contaminated soils and irrigation water $[7,8]$. Rich calcium materials, which may increase soil $\mathrm{pH}$, reduce

* Corresponding author.

Email: nvchuong@agu.edu.vn

https://doi.org/10.21924/cst.6.2.2021.515 the As mobility of soil and contribute to the soil fertility for plants are the As immobilization of soil and As accumulation by plants $[9,10]$.

The application of lime combined with inorganic fertilizers and river water irrigation are the best way to reduce the As accumulation of agricultural soils, which can cause the increase of the As accumulation of plants [11,12]. The coapplication of lime and NPK fertilizer, which raises $\mathrm{pH}$ and precipitated As element in crop soils is the high technology for the effective and unshaken productivity [13]. The primary objective of this research is to rate the impacts of lime, As contamination soils and irrigated waters on the growth, yield and As uptake of rice, corn and mung bean in the greenhouse condition.

\section{Materials and Methods}

Greenhouse experiments was designed at the greenhouse of An Giang University from January to June, 2021. Eighty four plastic pots that were taken experiment 1: three plant types $\mathrm{x}$ two irrigation water types $\mathrm{x}$ two soil types $\mathrm{x}$ four repeats + experiment 2: three plant types $\mathrm{x}$ three lime ratios $\mathrm{x}$ four repeats $=84$ were $25 \mathrm{~cm}$ in diameter and $25 \mathrm{~cm}$ in height. $3 \mathrm{~kg}$ of soils per pot were collected from Phuoc Hung. In the next stage, Lime was mixed with the soil before 15 days sowing with NPK fertilizer as shown in table 4. There were 21 different treatments for two experiments (experiment 1 and 2 
with twelve and nine treatments, respectively). Twelve treatments of the experiment 1 included: T1, T2, T3, T4, T5, T6, T7, T8, T9, T10, T11 and T12 and nine treatments of experiment 2: T13, T14, T15, T16, T17, T18, T19, T20 and T21 as presented in table 3 and table 4 . Two irrigation waters included (i) without As contamination water (river water), and (2) the As contamination irrigation water of $200 \mu \mathrm{g} \mathrm{As} / \mathrm{L}$ (diluted $200 \mu \mathrm{g}$ As + without As contamination water $=1$ litre) in the nethouse experiment condition. Two nethouse experiments, which were amended for three plants of rice, maize and mung bean had: (experiment 1) two irrigation water types (without As polluted water and water of $200 \mu \mathrm{g} \mathrm{As} / \mathrm{L}$ ) and two soil types (inside and outside the dyke) in table 3; (experiment 2) three $\mathrm{CaO}$ rates $(0.0,7.0$ and $9.0 \mathrm{t} / \mathrm{ha}$ ), the soil inside the dyke and irrigated water of $200 \mu \mathrm{g}$ As/L (dilute 200 $\mu \mathrm{g}$ As + without As contamination water $=1$ litre) in table 4 .

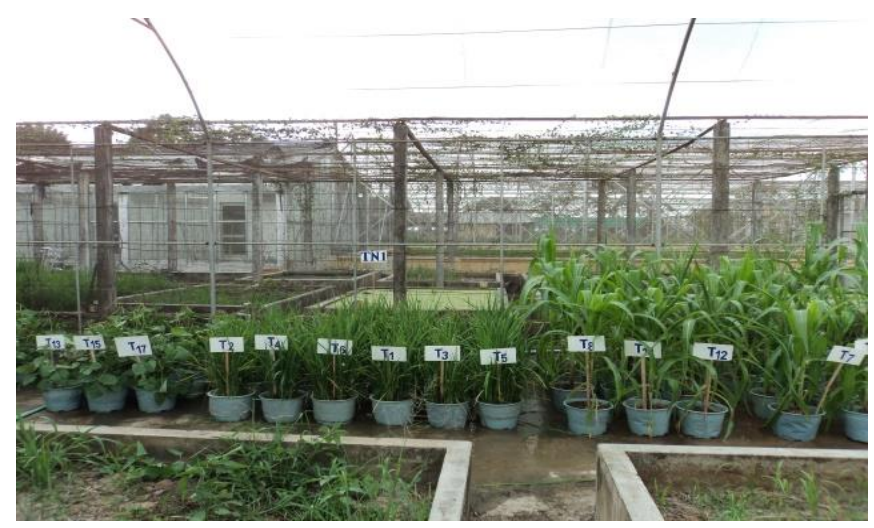

(a) experiment 1

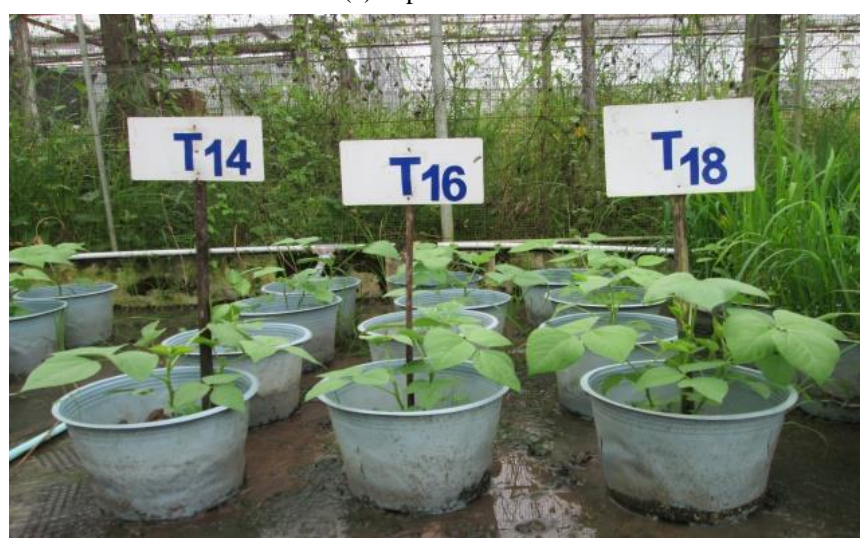

(b) experiment 2

Fig.1. several pictures of the greenhouse experiment

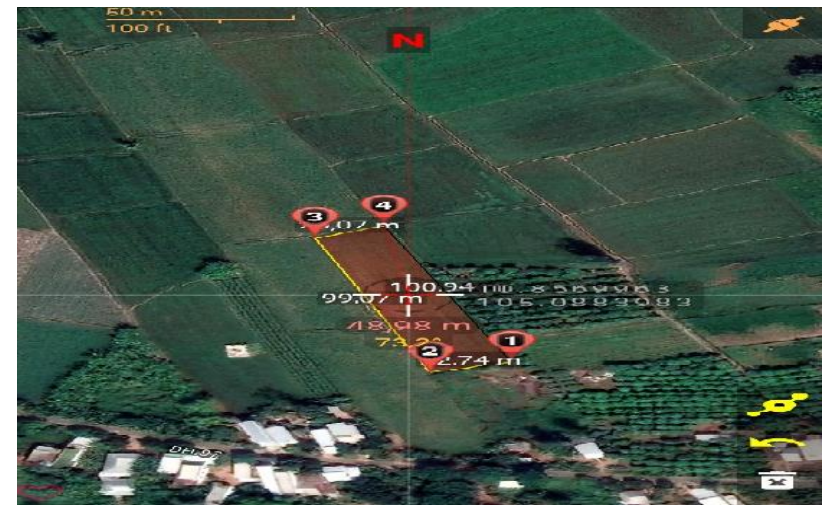

Fig.2. The experimental site, Phuoc Hung commune, An Phu district
The seeds of rice OM5451, maize DK 888 and mung bean ĐX 208 were collected from Institute for Agriculture of Loc Troi Group, An Giang, Vietnam. The growing technology and fertilizer rates are shown in table 1 . The crop harvest was from the first to end of June, 2021 for three plant types. The samples of two soil types were taken from inside the dyke and outside the dyke at An Phu district, which were collected in the soil depth $(0-20 \mathrm{~cm})$ for the greenhouse experiment (figure 1). The physical-chemical characteristics of first soil are shown in table 2 .

Table 1. The growth of three plant types in the nethouse condition (following

\begin{tabular}{|c|c|c|c|c|}
\hline Plants & $\begin{array}{c}\text { Pot } \\
\text { diameter } \\
(\mathrm{cm})\end{array}$ & Seeds/pot & $\begin{array}{c}\text { Soil } \\
\text { weight/pot } \\
(\mathrm{kg})\end{array}$ & Manures (kg/ha) \\
\hline Rice & 25 & 10 & 5 & $\begin{array}{l}100 \mathrm{~N}-60 \mathrm{P}_{2} \mathrm{O}_{5^{-}} \\
30 \mathrm{~K}_{2} \mathrm{O}\end{array}$ \\
\hline Maize & 25 & 2 & 10 & $\begin{array}{l}250 \mathrm{~N}-90 \mathrm{P}_{2} \mathrm{O}_{5^{-}} \\
60 \mathrm{~K}_{2} \mathrm{O}\end{array}$ \\
\hline Mungbean & 25 & 2 & 5 & $\begin{array}{l}40 \mathrm{~N}-60 \mathrm{P}_{2} \mathrm{O}_{5^{-}} \\
50 \mathrm{~K}_{2} \mathrm{O}\end{array}$ \\
\hline
\end{tabular}

Table 2. Physical-chemical properties of water and soil of the initial experiment

\begin{tabular}{|c|c|c|c|}
\hline Parameters & Value & Parameters & Value \\
\hline Silt $(\%)$ & 55.6 & Total N (\%) & 0.04 \\
\hline Clay $(\%)$ & 12.7 & Available $\mathrm{P}, \mathrm{mg} / \mathrm{kg}$ & 1.12 \\
\hline Sand & 31.7 & Exchangeable K meq/100g & 0.10 \\
\hline Soil texture & $\begin{array}{l}\text { Silt sand } \\
\text { loam }\end{array}$ & Organic matter $(\%)$ & 0.71 \\
\hline $\begin{array}{l}\text { Soi } \mathrm{pH} \text { inside the } \\
\text { dike }\end{array}$ & 4.75 & $\begin{array}{l}\text { Total As (soil inside the } \\
\text { dyke), } \mathrm{mg} / \mathrm{kg}\end{array}$ & 54.6 \\
\hline $\begin{array}{l}\text { Soil } \mathrm{pH} \text { outside } \\
\text { the dike }\end{array}$ & 5.52 & $\begin{array}{l}\text { Total As (soil outside the } \\
\text { dyke), } \mathrm{mg} / \mathrm{kg}\end{array}$ & 12.5 \\
\hline
\end{tabular}

Table 3. Treatments of different irrigation waters and soils on the As uptake of rice, maize and mung bean (experiment 1 )

\begin{tabular}{|c|c|c|c|}
\hline Treatment & Plants & Soil & $\begin{array}{c}\text { Irrigation waters } \\
\left.\text { (As content, } \mu \mathrm{g} \mathrm{L}^{-1}\right)^{*}\end{array}$ \\
\hline $\mathrm{T} 1$ & \multirow{4}{*}{ Rice } & \multirow{2}{*}{ Inside the dyke } & 0 (unpolluted water) \\
\hline $\mathrm{T} 2$ & & & 200 (polluted water) \\
\hline $\mathrm{T} 3$ & & \multirow{2}{*}{ outside the dyke } & 0 (unpolluted water) \\
\hline $\mathrm{T} 4$ & & & 200 (polluted water) \\
\hline $\mathrm{T} 5$ & \multirow{4}{*}{ Maize } & \multirow{2}{*}{ Inside the dyke } & 0 (unpolluted water) \\
\hline T6 & & & 200 (polluted water) \\
\hline $\mathrm{T} 7$ & & \multirow{2}{*}{ outside the dyke } & 0 (unpolluted water) \\
\hline $\mathrm{T} 8$ & & & 200 (polluted water) \\
\hline T9 & \multirow{4}{*}{$\begin{array}{c}\text { Mung } \\
\text { bean }\end{array}$} & \multirow{2}{*}{ Inside the dyke } & 0 (unpolluted water) \\
\hline T10 & & & 200 (polluted water) \\
\hline $\mathrm{T} 11$ & & \multirow{2}{*}{ outside the dyke } & 0 (unpolluted water) \\
\hline $\mathrm{T} 12$ & & & 200 (polluted water) \\
\hline
\end{tabular}

Note:* The As contamination irrigation water of $200 \mu \mathrm{g} \mathrm{As} / \mathrm{L}$ (dilute $200 \mu \mathrm{g}$ As + without As contamination water $=1$ litre) 
Soil samples were collected before and after each experimental pot; meanwhile, the plant samples were collected at the harvest. The properties of soil samples were determined by using methods for texture, total As, $\mathrm{pH}$, organic matter, total $\mathrm{N}$, available $\mathrm{P}$ and exchangeable $\mathrm{K}$ contents. Soil $\mathrm{pH}$ was determined by $\mathrm{pH}$ meter and total As concentrations of all samples were determined using Atomic Absorption Spectrophotometric (AAS). The yields (ton/ha) of rice, maize and mung bean were calculated after analyzing the moisture percentage. The variance analysis for the significant differences of treatments was done using Statgraphics Centurion XIX and the Multiple Range test of Duncan at LSD $<0.05$ or $<0.01$.

Table 4. Treatments of various lime rates of rice, maize and mung bean (experiment 2)

\begin{tabular}{|c|c|c|c|c|}
\hline Treatment & Plants & Soil & Irrigation water & $\begin{array}{c}\text { Lime } \\
\text { (ton } \mathrm{CaO} / \mathrm{ha} \text { ) }\end{array}$ \\
\hline T13 & \multirow{3}{*}{ Rice } & \multirow{9}{*}{$\begin{array}{c}\text { Inside } \\
\text { the dyke }\end{array}$} & \multirow{9}{*}{$\begin{array}{c}200 \mu \mathrm{g} \text { As/ L) } \\
\text { (contaminated } \\
\text { water) }\end{array}$} & 0 \\
\hline $\mathrm{T} 14$ & & & & 7 \\
\hline $\mathrm{T} 15$ & & & & 9 \\
\hline $\mathrm{T} 16$ & & & & 0 \\
\hline $\mathrm{T} 17$ & Maize & & & 7 \\
\hline T18 & & & & 9 \\
\hline T19 & & & & 0 \\
\hline $\mathrm{T} 20$ & $\begin{array}{l}\text { Mung } \\
\text { bean }\end{array}$ & & & 7 \\
\hline $\mathrm{T} 21$ & & & & 9 \\
\hline
\end{tabular}

\section{Results And Discussion}

\subsection{Effects of soil and irrigation water on As uptake of rice, maize and mung beans}

The results as presented in Figure. 3 showed that the average soil $\mathrm{pH}$ of rice, maize and mung bean was in the range of 6.3 to 6.6 for the $0.0 \mu \mathrm{g}$ As/L irrigation water treatments and 6.0 to 6.4 for the $200 \mu \mathrm{g}$ As/L irrigation water treatments. The average soil $\mathrm{pH}$ of rice, maize and mung bean in the $200 \mu \mathrm{g} \mathrm{As} \mathrm{L}^{-1}$ irrigation water treatments was found lower than that of in the $0.0 \mu \mathrm{g}$ As/L irrigation water treatments (figure 3 ). The results depicted in figure 1 showed that soil $\mathrm{pH}$ of the end of the whole experiments increased adequately compared to the initial soil $\mathrm{pH}$ of the experiment. In addition, the cultivation method of each crop also had the impact on soil $\mathrm{pH}$. The soil $\mathrm{pH}$ of rice treatments tended to be lower and significantly different from the soil $\mathrm{pH}$ of maize and mung beans treatments. The different types of plant and the As presence of irrigation water reduced the soil $\mathrm{pH}$ (figure 3 ). The arsenic elements of the polluted irrigation water were in the forms of arsenate $\left(\mathrm{H}_{2} \mathrm{AsO}^{4-}, \mathrm{HAsO}^{42-}\right)$ or arsenic $\left(\mathrm{H}_{3} \mathrm{AsO}_{3}\right)$ in soils and released $\mathrm{H}^{+}$, which caused the reduction of the soil $\mathrm{pH}$ [14]. Arsenic concentration in soil and plants was affected by irrigation water conditions and soil $\mathrm{pH}$. The As availability and movement in soil were determined by the soil $\mathrm{pH}$, which was affected by the high or low As concentration of crop irrigation water [15].

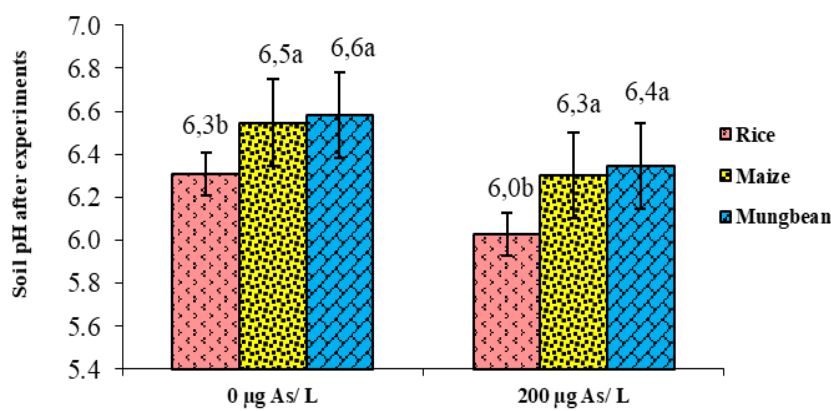

Fig.3. Effect of different irrigation waters on soil $\mathrm{pH}$ at the end of experiment

\subsection{Effects of soil and irrigation water on the As uptake of rice, maize and mung beans}

The results in table 5 showed that stem and seed As contents of rice, maize and mung bean were in the range of 298 to $591 \mu \mathrm{g} / \mathrm{kg}$ and 102 to $382 \mu \mathrm{g} / \mathrm{kg}$, respectively. The highest As contents of stems $(591 \mu \mathrm{g} / \mathrm{kg})$ and seeds (382 $\mu \mathrm{g} / \mathrm{kg}$ ) was obtained at mung bean treatments. The As accumulation of mung bean stems and seeds was the highest value, followed by the rice stems $(355 \mu \mathrm{g} / \mathrm{kg})$ and seeds $(166$ $\mu \mathrm{g} / \mathrm{kg}$ ) and the lowest As value of the maize stems (298 $\mu \mathrm{g} / \mathrm{kg}$ ) and seeds $(102 \mu \mathrm{g} / \mathrm{kg}$ ) (table 5). The same conditions of farming soil and irrigation water had the different As absorption of plant bodies with different crop types. The average As content of stems $(590 \mu \mathrm{g} / \mathrm{kg})$ and seeds $(341 \mu \mathrm{g} /$ $\mathrm{kg}$ ) of rice, maize and mung bean on soils inside the dyke had higher than those of stems $(190 \mu \mathrm{g} / \mathrm{kg})$ and seeds $(108 \mu \mathrm{g} / \mathrm{kg})$ compared with the soil outside the dyke (table 5).

Table 5. Effects of different soils and irrigation water on As contents of rice, maize and mung bean

\begin{tabular}{|c|c|c|}
\hline \multirow{2}{*}{ Treatment } & \multicolumn{2}{|c|}{ As contents $(\mu \mathrm{g} / \mathrm{kg})$} \\
\hline & Stem & seed \\
\hline \multicolumn{3}{|l|}{ Plant (A) } \\
\hline -Rice & $355^{\mathrm{b}}$ & $166^{\mathrm{b}}$ \\
\hline - Maize & $298^{c}$ & $102^{\mathrm{c}}$ \\
\hline - Mung bean & $591^{\mathrm{a}}$ & $382^{\mathrm{a}}$ \\
\hline \multicolumn{3}{|l|}{ Soil (B) } \\
\hline - Inside the dyke & $590^{\mathrm{a}}$ & $341^{\mathrm{a}}$ \\
\hline - Outside the dyke & $190^{\mathrm{b}}$ & $108^{\mathrm{b}}$ \\
\hline \multicolumn{3}{|l|}{ Irrigation water (C) } \\
\hline$-0 \mu \mathrm{g}$ As $\mathrm{L}^{-1}$ & $104^{\mathrm{b}}$ & $50.6^{\mathrm{b}}$ \\
\hline$-200 \mu \mathrm{g}$ As $L^{-1}$ & $562^{\mathrm{a}}$ & $479^{\mathrm{a}}$ \\
\hline $\mathrm{F}(\mathrm{A})$ & $* *$ & $* *$ \\
\hline $\mathrm{F}(\mathrm{B})$ & $* *$ & $* *$ \\
\hline $\mathrm{F}(\mathrm{C})$ & $* *$ & $* *$ \\
\hline $\mathrm{F}(\mathrm{Ax})$ & $* *$ & Ns \\
\hline $\mathrm{F}(\mathrm{AxC})$ & Ns & $* *$ \\
\hline $\mathrm{F}(\mathrm{BxC})$ & $* *$ & $* *$ \\
\hline $\mathrm{F}(\mathrm{AxBxC})$ & Ns & Ns \\
\hline $\mathrm{CV}(\%)$ & 22.7 & 11.3 \\
\hline
\end{tabular}


The As accumulation of rice, maize and mung bean bodies in stems $(562 \mu \mathrm{g} / \mathrm{kg})$ and seeds $(479 \mu \mathrm{g} / \mathrm{kg})$ in $200 \mu \mathrm{g}$ As/L irrigated treatments were higher than $81.5 \%$ in stems and $89.4 \%$ in seeds those of unpolluted irrigation water treatments. There were considerable differences of the As accumulation of plant bodies when watering for crops by unpolluted or polluted water. The results as shown in table 5 could interpret the same soil and irrigation water type, which may absorb the different As levels of plant bodies for each different plant. The highest As accumulation of stems and seeds of mung bean was compared by those of rice and maize. Furthermore, the As accumulation of stems and seeds of plant bodies on soils inside the dyke were higher than those of soils outside the dyke. Because the As concentration of the soil inside the dyke was contaminated more than that of the soil outside the dyke and significantly different among plants (A) and soil (B); soil (B) and water (C) at $1 \%$ level. Prior studies proved that As polluted water irrigation not only increased the soil As concentration but also raised As accumulation of stems and seeds of crops [16,6]. The use Arsenic polluted water irrigation already lessened the yield and gradually increased the arsenic accumulation of field soils [17].

\subsection{Effects of lime ratios on As uptake of rice, maize and mung bean}

The soil $\mathrm{pH}$, which ranged from 6.1.to 7.8 for all treatments raised from $6.1,7.2$ to 7.3 (rice), $6.1,6.8$ to 7.5 (maize) and 7.2, 7.6.to 7.8 (mung bean) at 0.0, 7.0 to 9.0 tons $\mathrm{CaO} / \mathrm{ha}$, respectively and $\mathrm{LSD}<0.01$ (figure 4). The soil $\mathrm{pH}$ raised sufficiently in lime addition treatments compared without lime treatments in the initial experiment, which obtained the maximum $\mathrm{pH}$ (7.8) of mung bean at the MBL9 (9.0 tons $\mathrm{CaO} / \mathrm{ha}$ ) and the minimum $\mathrm{pH}$ (6.1) of maize at the ML4 (0.0 tons $\mathrm{CaO}$ / ha. The As accumulation of plant bodies of rice, maize and mung bean was completely various among three plants with three lime ratios of $0.0,7.0$ and 9.0 tons $\mathrm{CaO} / \mathrm{ha}$. The lime supply for farming soils may raise the soil $\mathrm{pH}$ of fields from three to six lime amended weeks being conditional on lime types [18]. The lime supplementation not only increases soil $\mathrm{pH}$ but also reduces the As accumulation of plants and increases crop yield [19]. The movability and bioavailability of soil As could raise adequately when reducing soil $\mathrm{pH}$. Therefore, the immovability and bioavailability decrease of soil As by the lime supplementation has been the indefectible technology [20,21].
Table 6. Effects of lime ratios on As contents of rice, maize and mung bean

\begin{tabular}{lcc}
\hline \multirow{2}{*}{ Treatment } & \multicolumn{2}{c}{ As contents $(\mu \mathrm{g} / \mathrm{kg})$} \\
& Stem & Seed \\
\hline Plant $(\mathrm{A})$ & & \\
-Rice & $649 \mathrm{~b}$ & $422 \mathrm{~b}$ \\
- Maize & $113^{\mathrm{c}}$ & $104^{\mathrm{c}}$ \\
- Mung bean & $1,240^{\mathrm{a}}$ & $659^{\mathrm{a}}$ \\
Lime $(\mathrm{B})$ & & \\
-0.00 ton $\mathrm{CaO} /$ ha & $998^{\mathrm{a}}$ & $589^{\mathrm{a}}$ \\
-7.00 tons $\mathrm{CaO} /$ ha & $617^{\mathrm{b}}$ & $271^{\mathrm{b}}$ \\
-9.0 tons $\mathrm{CaO} / \mathrm{ha}$ & $613^{\mathrm{b}}$ & $268^{\mathrm{b}}$ \\
$\mathrm{F}(\mathrm{A})$ & $* *$ & $* *$ \\
$\mathrm{~F}(\mathrm{~B})$ & $* *$ & $* *$ \\
$\mathrm{~F}(\mathrm{~A} \times \mathrm{B})$ & $* *$ & $* *$ \\
$\mathrm{CV}(\%)$ & 21.7 & 18.9 \\
\hline Note: $* *$ significant difference at $1 \%(p \leq 0.01)$. &
\end{tabular}

The As accumulation of stems and seeds of mung beans, which was the highest As concentration were 1,240 and 659 $\mu \mathrm{g} / \mathrm{kg}$, followed by the stem $(649 \mu \mathrm{g} / \mathrm{kg})$ and seed $(422 \mu \mathrm{g} / \mathrm{kg})$ of rice; while the lowest As value of the stem $(113 \mu \mathrm{g} / \mathrm{kg})$ and seed $(104 \mu \mathrm{g} / \mathrm{kg})$ of maize was completely various among treatments at $1 \%$ (table 6). Similarly, the highest As content of plant bodies, obtained in non-lime supplement had the average As concentration of $998 \mu \mathrm{g} / \mathrm{kg}$ (stem) and 589 $\mu \mathrm{g} / \mathrm{kg}$ (seed), followed by the stem $(617 \mu \mathrm{g} / \mathrm{kg})$ and seed $(271$ $\mu \mathrm{g} / \mathrm{kg}$ ) of 7.0 tons $\mathrm{CaO} / \mathrm{ha}$ application. The lowest As value of the stem $(613 \mu \mathrm{g} / \mathrm{kg})$ and seed $(268 \mu \mathrm{g} / \mathrm{kg})$ of 10.0 tons $\mathrm{CaO} /$ ha application was completely various among treatments at $1 \%$ (table 6). The As concentration of plant bodies was found insignificantly various between the treatment of 7.0 and 90.0 tons $\mathrm{CaO} /$ ha. The general results proved that As uptake of mung bean had the highest level, followed by rice and As value of maize at the lowest one. The application of 7.0 and 9.0 tons $\mathrm{CaO}$ per ha reduced the As accumulation of stems and seeds becoming lower than the one without lime treatments. The As accumulation of plants was adequately influenced by the lowe $\mathrm{pH}$ in view of the reaction between $\mathrm{Fe}$ and $\mathrm{Al}$ hydroxide and soil As types [22]. Negative correlation between the $\mathrm{pH}$ and As hoard of plants could increase significantly soil $\mathrm{pH}$ values [23]. The lime application may raise the soil $\mathrm{pH}$, which is the main cause to reduce the As uptake of plants because of the immovability of soil As [24].

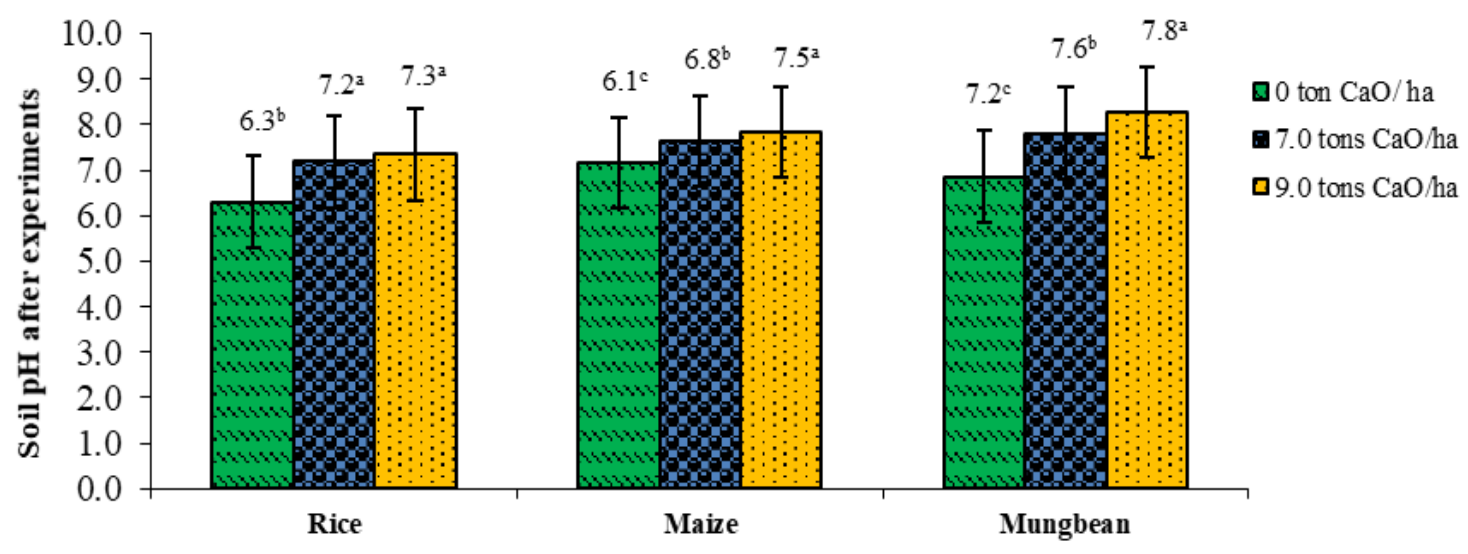

Fig.4. Effect of different lime ratios on soil $\mathrm{pH}$ after the experiment 
Lime amendment raised the agricultural soil $\mathrm{pH}$ to be contingent upon lime rates [25].

\subsection{Effects of lime ratios on the yield components of rice, maize and mung bean}

All highest 1,000 seeds weights of rice $(27.0$ gr), maize (270 gr) and mung bean (100gr) in T14, T17 and T20 treatments were attained by the amendment of 7.0 tons $\mathrm{CaO} / \mathrm{ha}$. The followed values were attained by RL3 (25.4 gr) of rice and mung bean $(90.9 \mathrm{gr})$ in the treatments of 9.0 tons $\mathrm{CaO} / \mathrm{ha}$. The lowest weight of rice, maize and mung bean was obtained by 24.6, 260 and 91.8 gr at T13, T16 and T19 treatments (no lime) (table 7). Similar to the 1,000 seeds weight, the number of pod per pot of rice, maize and mung bean raised significantly (at 5\% level) with the increasing lime rates from $0.0,7.0$ to 9.0 tons $\mathrm{CaO} /$ ha. The 1,000 seeds weight of three plantswere adequately impacted by the lime supplementation. All highest values of 1,000 seeds weight of three plants reached at 7.0 tons $\mathrm{CaO} /$ ha treatments and the lowest values were at none lime treatments (table 7). The results as shown in table 7 showed that number of seeds per pod of rice, maize and mung bean had sufficiently been influenced by various lime rates and sufficiently differences at $5 \%$ level. The highest values of three plants were attained by the lime application of 7.0 tons per ha, followed at 9.0 tons/ha and the minimum value without lime supplementation $(0.0$ tons $\mathrm{CaO} /$ ha (table 7). Plants were tilled on As polluted soils and were irrigated by As polluted waters, which may lessen the mature and production of fields [4,5]. The line amendment, aimed to increase soil $\mathrm{pH}$ and the As immovability of soil may increase the yield of fields [26]. However, the application of high lime level could increase to unsuitable $\mathrm{pH}$ for the growth of plants [27].

\section{Conclusion}

The results of this study powerfully proved that the application of 7.0 and 9.0 tons $\mathrm{CaO}$ per ha increased soil $\mathrm{pH}$ which caused the significant reduction of the As accumulation of stems and seeds of rice, maize and mung bean. The application of 7.0 tons $\mathrm{CaO}$ per ha combined with the As unpolluted water irrigation was found as the best way to decrease the As accumulation. The highest yield of rice, maize and mung bean reached at lime amendment treatments of 7.0 tons $\mathrm{CaO}$ per ha in the agricultural cultivation on As polluted soils and the As polluted water irrigation. The new discovery of this study found out the As accumulation of stems and seeds mung bean with the highest value when comparing to those of rice and maize. The amendment of 9.0 tons $\mathrm{CaO} / \mathrm{ha}$ had so high soil $\mathrm{pH}$ of soil that restricted the growth and yield of crops.

Table 7. Yield components and production of rice, maize and mung bean affected by lime ratios

\begin{tabular}{|c|c|c|c|}
\hline Treatment & 1,000 seeds weight (gr) & No.of pods/ pot & No.of seeds/ pod \\
\hline \multicolumn{4}{|l|}{-Rice (A) } \\
\hline - 0.00 ton $\mathrm{CaO} / \mathrm{ha}$ & $24.6^{c}$ & $25.6^{\mathrm{a}}$ & $59.1^{\mathrm{b}}$ \\
\hline 7.00 tons $\mathrm{CaO} / \mathrm{ha}$ & $27.0^{\mathrm{a}}$ & $25.0^{\mathrm{a}}$ & $60.9^{\mathrm{a}}$ \\
\hline - 9.0 tons $\mathrm{CaO} / \mathrm{ha}$ & $25.4^{\mathrm{b}}$ & $21.6^{\mathrm{b}}$ & $59.0^{\mathrm{b}}$ \\
\hline \multicolumn{4}{|l|}{ Maize (B) } \\
\hline - 0.00 ton $\mathrm{CaO} / \mathrm{ha}$ & $260^{\mathrm{b}}$ & $3.05^{\mathrm{c}}$ & $367^{\mathrm{b}}$ \\
\hline - 7.00 tons $\mathrm{CaO} / \mathrm{ha}$ & $270^{\mathrm{a}}$ & $4.00^{\mathrm{a}}$ & $482^{\mathrm{a}}$ \\
\hline - 9.0 tons $\mathrm{CaO} / \mathrm{ha}$ & $270^{\mathrm{a}}$ & $3.55^{\mathrm{b}}$ & $483^{\mathrm{a}}$ \\
\hline \multicolumn{4}{|l|}{ Mung bean (C) } \\
\hline - 0.00 ton $\mathrm{CaO} / \mathrm{ha}$ & $90.8^{b}$ & $30.3^{c}$ & $10.0^{\mathrm{c}}$ \\
\hline - 7.00 tons $\mathrm{CaO} / \mathrm{ha}$ & $100^{\mathrm{a}}$ & $34.0^{\mathrm{a}}$ & $12.9^{\mathrm{a}}$ \\
\hline - 9.0 tons $\mathrm{CaO} / \mathrm{ha}$ & $91.9^{\mathrm{ab}}$ & $31.8^{\mathrm{b}}$ & $11.1^{\mathrm{b}}$ \\
\hline $\mathrm{F}(\mathrm{A})$ & $*$ & $*$ & $*$ \\
\hline $\mathrm{F}(\mathrm{B})$ & $*$ & $*$ & $*$ \\
\hline $\mathrm{F}(\mathrm{C})$ & $*$ & $*$ & $*$ \\
\hline $\mathrm{CV}_{\mathrm{A}}(\%)$ & 5.80 & 4.50 & 6.80 \\
\hline $\mathrm{CV}_{\mathrm{B}}(\%)$ & 3.10 & 17.0 & 6.10 \\
\hline $\mathrm{CVc}(\%)$ & 1.50 & 8.80 & 11.9 \\
\hline
\end{tabular}

*significant difference at $5 \%(\mathrm{P}<0.05)$.

\section{References}

1. N.M. Khan, M. Mobin, Z.K. Abbas, S.A. Alamri, Fertilizers and their contaminants in soils, surface and groundwater. Ethiop. J. Biol. Sci. 5(2018) 225-240.

2. N.V. Chuong, Effects of alternate wetting and drying irrigation and different ratios of lime on the arsenic uptake and yield of rice OM18. Annals of R.S.C.B. 25(2021) 20396 - 20405.
3. S. Robles, J. Abraham, C. Saldaña-Robles, Ozuna, A.J. GutiérrezChávez, The negative effect of arsenic in agriculture: irrigation water, soil and crops, state of the art. Applied Ecology And Environmental Research. 16(2018)1533-1551.

4. U. Kramar, S. Norra, Z. Berner, M. Kiczka, D. Chandrasekharam, On the distribution and speciation of arsenic in the soil-plant-system of a rice 
field in WestBengal, India: A $\mu$-synchrotron techniques based case study. Applied Geochemistry. 77(2015) 4-14.

5. G. Dixit, et al., Reduced arsenic accumulation in rice (Oryza sativa L.) shoot involves sulfur mediated improved thiol metabolism, antioxidant system and altered arsenic transporters. Plant Physiologyogy and Biochemistry. 99(2016) 86-96.

6. N.V. Chuong, H.T. Hung, Evaluation of arsenic pollution ability in soil, water, seed and effects of lime on the arsenic uptake and yield of mungbeans. Turkish Online Journal of Qualitative Inquiry (TOJQI). 12(2021)1061-1066.

7. Z.J. Fu, et al., Genetic analysis of arsenic accumulation in maize using QTL mapping. Scientific Reports.6 (2016) 21292

8. D. Ding, et al., Identification of QTLs for Arsenic Accumulation in Maize (Zea mays L.) using a RIL population. PLoS ONE. 6(2011) 25646.

9. C.Y. Wei, T.B. Chen, The ecological and chemical characteristics of plants in the areas of high arsenic levels. Acta Phytoecologgic Sinica. 26 (2021) 695-700

10. Z. Zhao, et al., Genetic-based dissection of arsenic accumulation in maize using a genome-wide association analysis method. Plant Biotechnology Journal. 16(2018) 1085-1093.

11. R. Requejo, M. Tena, Influence of glutathione chemical effectors in the response of maize to arsenic exposure. Journal of Plant Physiology.169(2012) 649-656.

12. D.H. Moon D. Dermatas, N. Menounou, Arsenic immobilization by calcium-arsenic precipitates in lime treated soils. Science Total Environment. 330(2014) 171-85.

13. N.S. Bolan, V.P. Duraisamy, Role of inorganic and organic soil amendments on immobilization and phytoavailability of heavy metals: a review involving specific case studies. Aust. J.Soil Res. 41(2015) 533555.

14. G. Delplace, et al., Accumulation of heavy metals in phytoliths from reeds growing on mining environments in Southern Europe. Sci. Total Environ. 712 (2020) 135595

15. H.G. Min, M.S. Kim, J.G. Kim, Effect of soil characteristics on arsenic accumulation in phytolith of gramineae (Phragmites japonica) and fern (Thelypteris palustris) near the gilgok gold mine. Sustainability. 13(2021) 3421
16. Saldaña-Robles, et al., The negative effect of arsenic in agriculture: irrigation water, soil and crops, state of the art. Applied Ecology and Environmental Research. 16(2018)1533-1551.

17. E.A. Ruíz-Huerta et al., Arsenic contamination in irrigation water, agricultural soil and maize crop from an abandoned smelter site in Matehuala, Mexico. Journal of Hazardous Materials. 339(2017) 330-339.

18. T. Suswanto, J. Shamshuddin, S.S. Omar, P. Mat, Alleviating an acid sulfate soil cultivated to rice (Oryza sativa) using ground magnesium limestone and organic fertilizer. J. Soil Sci. Environ. 99(2007) 1-9.

19. X. Liu, et al., Arsenic-induced nutrient uptake in As-hyperaccumulator Pteris vittata and their potential role to enhance plant growth. Chemosphere, 198 (2018) 425-431.

20. S. Quazi, R. Datta, D. Sarkar, Effect of soil types and forms of arsenical pesticide on rice growth and development. Int. J. Environ. Sci. Technol. $8(2011) 450-460$.

21. S. Chatterjee, et al., Use of wetland plants in bioaccumulation of heavy metals. In Plant-Based Remediation Processes. Gupta, D.K., Ed.; Springer: Berlin, Heidelberg, Germany. 1(2013) 117-13.

22. A. Signes-Pastor, F. Burló, K. Mitra, A.A. Carbonell-Barrachina, Arsenic biogeochemistry as affected by phosphorus fertilizer addition, redox potential and pH in a West Bengal (India) soil. Geoderma. 137(2007) 504-510.

23. V. Chandrakar, A. Dubey, S. Keshavkant, Modulation of antioxidant enzymes by salicylic acid in arsenic exposed Glycine max L. J. Soil Sci. Plant Nutr.169(2016) 662-676.

.24. A. Rosilawati, J. Shamshuddin, Effects of incubating an acid sulfate soil treated with various liming materials under submerged and moist conditions on pH, Al and Fe. Afr. J. Agric. Res. 9 (2014) 94-112

25 B. Minasny, S.Y. Hong, A.E. Hartemink, Y.H. Kim, S.S. Kang, Soil pH increase under paddy in South Korea between 2000 and 2012. Agriculture, Ecosystems \& Environment. 221(2016) 205-213.

26. Dora Neina, The role of soil $\mathrm{pH}$ in plant nutrition and soil remediation. Applied and Environmental Soil Science. 1(2019)1-9.

27. C.J.M. Rosas, et al., Arsenic accumulation in maize crop (Zea mays): A review. Science of The Total Environment. 1(2014)176-187. 